\title{
Assessment of Mango Pests, Diseases and Orchard Management Practices in West Nile Zone of Uganda
}

\author{
Dan Acema $^{1, ~ *, ~ B a r o n ~ A s i k u ~}{ }^{1}$, Emmanuel Odama $^{2}$, Dickson Egama ${ }^{2}$ \\ ${ }^{1}$ Agroforestry Unit of Abi Zonal Agricultural Research and Development Institute, Arua, Uganda \\ ${ }^{2}$ Soil Fertility Enhancement Unit of Abi Zonal Agricultural Research and Development Institute, Arua, Uganda \\ Email address: \\ acemaowens@gmail.com (D.Acema),baronasiku@yahoo.com (B. Asiku),odama.e7@gmail.com (E. Odama), \\ egama_dickson@yahoo.com (D. Egama) \\ ${ }^{*}$ Corresponding author
}

\section{To cite this article:}

Dan Acema, Baron Asiku, Emmanuel Odama, Dickson Egama. Assessment of Mango Pests, Diseases and Orchard Management Practices in West Nile Zone of Uganda. Agriculture, Forestry and Fisheries. Vol. 5, No. 3, 2016, pp. 57-63. doi: 10.11648/j.aff.20160503.15

Received: May 19, 2016; Accepted: May 28, 2016; Published: June 7, 2016

\begin{abstract}
Exotic mango varieties can improve the livelihood security and increase profitability of mango growers in Uganda. There are however, several factors like pests, diseases and orchard management practices which limit mango production and productivity. The study sought to investigate farmers' knowledge and perceptions of mango pests and diseases and orchard management practices in West Nile zone (WNZ) of Uganda. Farmers growing exotic mango varieties were selected from six districts namely, Arua, Maracha, Koboko, Yumbe, Moyo and Nebbi in WNZ. Both purposive and simple random sampling techniques were used to identify 90 respondents who were interviewed with a semi structured questionnaire. The data was analyzed both descriptively and inferentially. Chi square tests were used to analyze farmers' perception on pests and diseases. Multinomial logit was used to analyze factors influencing choice of orchard management practices. The results showed a significant variation in perception of farmers on incidence, severity and yield loss due to various pests (fruit flies, seed borer, termites, scales and mealy bugs) and, diseases (anthracnose, bacterial black spot, powdery mildew, algal leaf spot and sooty mould). Farmers' choice to take a particular management practice like pruning, spraying, manuring and mulching were influenced by age of mangoes, extension service, education level and sex. It was concluded that many pests and diseases of exotic mangoes existed in WNZ and sound scientific orchard management practices were still lacking among the mango farmers. The study recommended awareness creation on various mango pests and diseases, and capacity enhancement of farmers and extension staff on scientific orchard management practices.
\end{abstract}

Keywords: Exotic Mangoes, Management, Multinomial Logit, West Nile Zone

\section{Introduction}

The Mango, Mangifera indica L, which belongs to the family of Anacardiaceae, is one of the most important tropical and subtropical fruits of the world and is popular both in fresh and processed forms [1]. It is called as the king of fruits on account of its nutritive value, taste, attractive fragrance and health promoting qualities. In Uganda, mangoes are by far the most common fruit country-wide [2]. They are 'volunteer' fruits growing in all parts of the country by gift of nature and adapt to all ecological zones of the country, dry or humid, montane and lake shoreline. However, areas of highest intensity are those in the relatively hot and dry Northern, Northeastern and West Nile zones.

Traditionally in Uganda, mangoes have been known to grow wildly with little or no husbandry practices [2]. The mango varieties grown are predominantly local. Most local varieties are high in fiber and require less attention in their growing [3]. The Uganda government's call on households to produce high value and marketable crops has however led to introduction of exotic mango varieties in the country [2]. The exotic varieties are of superior qualities; they have higher juice yields, good flavor and no strings; and are more appealing to both the local and the international market [3]. Since their introduction in the country in late 1980's, the exotic mango varieties have spread to all mango growing 
areas of Uganda [2]. Some of the exotic mango varieties grown in West Nile zone of Uganda include; Tommy Atkins, Kent, Haden, Keit, Zillate, Palvin, Palmer, Alphonso, and Irwin among others [4].

Mango plant suffers from a number of pests and diseases at all stages of development i.e. right from nursery stage to grown-up tree stage. Even fruits at pre-harvest stages are affected making them unsuitable for marketing and export [5]. Some of the mango pests as reported by different authors include; beetles, fruit flies, red banded thrips, mango tip borer, scales and seed weevil [6, 7, 5, and 8]. While the diseases include; Anthracnose caused by fungus Colletotrichum gloeosporioides, bacterial black spot caused by Xanthomonas campestris $p v$ mangiferae-indicae, algal leaf spot caused by green alga parasite Cephaleuros virescens and Powdery mildew caused by fungus Oidium mangiferae $[9,10,11]$. There is generally poor management of mango pests and diseases among farmers in Uganda [4]. As such, some of the mango pests like fruit flies have been reported to have a devastating effect on mango production in Uganda [8]. Consequently, the existing level of productivity in mango growing belt of Uganda is disheartening [2].

Being a new agro-enterprise in West Nile Zone (WNZ), varied knowledge gaps exist on pests, diseases and fruit tree management of exotic mangoes among farmers. This is because possibilities of diseases and pests transfer from the origin of exotic varieties are high [12]. Besides, the crops may also be attacked by pests and diseases that might have been living on alternate wild plants that were of little concern to the farmers. All these are mysteries unknown to exotic mango farmers and researchers in WNZ. Accordingly, there is dearth of information about exotic mango pests, diseases, and orchard management practices in the zone. This study therefore, sought to establish farmers' knowledge and perceptions of mango pests and diseases and examine orchard management practices employed by farmers. Ascertaining various prevailing mango pests, diseases and orchard management practices in WNZ is useful to set research agendas, for planning campaign strategies and developing messages for communication to the farmers.

\section{Materials and Methods}

\subsection{Study Site}

The study was conducted in West Nile zone. The zone lies at $2^{\circ} 10^{\prime}$ and $3^{\circ} 49^{\prime}$ latitudes and $32^{\circ} 05^{\prime}$ longitudes in North Western part of Uganda. Six districts were covered in the study: Arua, Maracha, Koboko, Yumbe, Moyo and Nebbi districts.

\subsection{Survey}

A survey was conducted from June to August 2014 in six districts of WNZ. A total of 90 mango farmers were interviewed. Both random and purposive sampling techniques were used. Six exotic mango growing districts were purposively selected within the region and from each district, fifteen mango farmers with orchards under production with trees aged 5 years or older were randomly chosen for interviews guided by a semi structured questionnaire. Interviews were conducted with the selected individuals because they allowed face to face interaction between researchers and the respondents.

This made probing and explanation of unclear questions possible. The major variables covered in the questionnaire included; the socio-demographic factors, agronomic practices and the major mango pests and diseases. The content of the questionnaire and type of questions asked were agreed upon after key informant interviews. The questionnaire was pretested and revised.

Farmers' knowledge and perceptions on mango pests and diseases and major orchard management practices received special emphasis. To evaluate farmers' pest and disease perceptions, they were first asked to record the most important pest and disease problems. For each of the major pests and diseases, their incidence, severity and estimated yield loss were ranked on a 3-level scale (low, moderate and high) following [13]. On average, each questionnaire took 1.5 to 2.5 hours of interview with each farmer, followed by a visit to the orchard. The visit to the orchard was aimed at cross checking the answers given by the farmers. In every orchard visited, 10 trees were randomly selected and surveyed for pests, and symptoms of pests and diseases. The orchard management practices employed by farmers were also established.

Survey data were encoded and statistical analysis were accomplished using Statistical Package for Social Sciences version 16 software. Percentages were based on the number of respondents rather than using the total sample. In cases where multiple responses were obtained, total sample size was used. Chi square tests were used to analyze farmers' perception on pests and diseases. Multinomial logit was used to analyze factors influencing orchard management practices adopted by farmers.

\subsection{Description of the Multi Nomial Logit (MNL) Model}

Let $\mathrm{Y}$ denote a random variable taking the values $\{1,2 \ldots \mathrm{J}\}$ where $\mathrm{J}$ is a positive integer and let $\mathrm{X}$ denote a set of conditioning variables. Here, $\mathrm{Y}$ represents the aspects of orchard management practices (weeding, mulching, pruning, manuring and spraying) and $\mathrm{X}$ denotes the various sociodemographic and other factors. Assuming that each respondent practices a discrete, mutually exclusive aspect of orchard management practice which depends on the socio demographic characteristics and other factors $\mathrm{X}$, the sum of the probabilities is unity. Following [14], the MNL model for management practices is:

$$
\operatorname{Prob}(Y=j)=\frac{e^{X j \beta_{j}}}{\sum_{k=0}^{J} e^{X \beta_{k}}}, j=0,1, \ldots J
$$

Where $\beta_{j}$ is a vector of coefficients on each of the independent variables $X$.

The indeterminacy in the model Equation (1) needs to be removed. This can be achieved by assuming that $\beta_{0}=0$. This 
way the probabilities sum to one, so only $J$ parameter vectors are needed to determine the $J+1$ probabilities. Therefore, the probabilities can be estimated as:

$$
\operatorname{Prob}(Y=j / X)=\frac{e^{X \beta_{j}}}{1+\sum_{k=1}^{J} e^{X \beta_{k}}}, j=0,1, \ldots J ; \beta_{0} 0
$$

For $\mathrm{j}=1$, the binomial model form is obtained. The model implies that we can compute $J$ log-odds

$$
\operatorname{In}\left(\frac{\mathrm{P}_{\mathrm{ij}}}{\mathrm{P}_{\mathrm{ik}}}\right)=X_{i}^{\prime}\left(\beta_{j}-\beta_{k}\right)=X^{\prime} \beta_{j} \text { if } k=0
$$

For the independence of irrelevant alternatives (IIA) assumption to hold, $\mathrm{Pj} / \mathrm{Pk}$ should be independent of the remaining probabilities. The parameter estimates of the MNL model provide only the direction of the effect of independent variables on the dependent (response) variable, but estimates do not represent the actual magnitude of change and probabilities. According to [15], estimating the marginal effects which are functions of the probability itself and measure the expected change in probability of a particular choice being made with respect to a unit change in an independent variable from the mean solves this problem. Therefore, by differentiating equation (2) with respect to the explanatory variables, the marginal effects of the probabilities are:

$$
\delta j=\frac{\delta P_{j}}{\delta x}=P_{j}\left(\beta_{j}-\sum_{k=0}^{J} P_{k} \beta_{k}\right)=P_{j}\left(\beta_{j}-\bar{\beta}\right)
$$

\subsection{Variables}

The choice sets in the orchard management criteria included; "Weeding," "Pruning," "Spraying" "Manuring" and "Mulching." These constituted the dependent variables. Descriptive statistics were obtained and the option with the highest frequency in the choice set was taken as the base category. The independent variables consisted of; Age of mangoes, level of education, sex, age of respondents and extension services. All the independent variables are either metric or dichotomous in nature while the dependent variables are non-metric.

\section{Results and Discussions}

\subsection{Common Mango Pests and Diseases}

Farmers did not know most of the pests and diseases by name. They described them mostly as related to a particular symptom or by the plant part under attack. This helped the researchers to exactly identify the pests and diseases. The major mango pests and diseases reported by farmers in the West Nile zone have also been described as major problems in Vietnam [13] and Papua New Guinea [16].

\subsubsection{Pests}

Mango fruit fly was the most common pest mentioned by $87.8 \%$ of the respondents. The farmers complained that the pest caused enormous destruction to mango fruits leading to great losses. The incidence, severity and yield loss estimates due to the pest rated high in all the districts. The commonest species of mango fruit fly observed in all the orchards in the zone was Bactrocera invadens. This result is in agreement with [8] who reported $B$. invadens as the most prevalent fruit fly species in Uganda.

High yield loss due to mango fruit flies was estimated most in Maracha district (100\%) and least in Nebbi district (9\%). The disparity between the two districts could be due to the type of mango orchard establishments, management practices and mango varieties in the districts. It was noted that most mango orchards visited in Nebbi district were mixed with other fruit trees like citrus, guava and pawpaw that are alternative hosts for mango fruit flies [17]. Accordingly, this reduced the pressure of fruit flies on mango fruits. Conversely, in Maracha district where most mango orchards were established in pure stands, pressure of fruit flies was high. Besides, most orchards in Maracha district were poorly managed and all these led to escalation of the pest in the district. This result is consistent with [8] who reported that in poorly managed mango fields, damage and crop losses due to fruit flies can be up to $100 \%$.

Mango seed weevil (Deanolis albizonalis) was the second most mentioned pest in the region. High percentages of respondents reported incidence of seed weevil in all the districts. The percentage of respondents who estimated severity and yield loss due to the pest were significantly high ( $p=0.003$ and $p=0.001$ ) respectively in Maracha district. This could possibly be attributed to farmers' inadequate knowledge on management of the pest because [6] noted that where the pest is well managed, yield loss due to it can be greatly reduced.

Termites as a mango pest were reported by $47.8 \%$ of the respondents. The termites were easily identified by farmers and their damage on mango trees were in various forms depending on the species of termite involved. These included: stems cut near the base; attack just below the ground surface, extending upwards until the stem was ring barked or downwards until the tap root tapers off and was severed; roots were penetrated and hollowed out; stem was penetrated and galleries excavated within it. Earth tubes on the ground or trees, were common in termite infested areas. The damages caused by termites to trees have been reported elsewhere in Uganda by [18]. Farmers reported the level of termite damage to mango trees to be most severe in dry periods. A similar negative relationship between termite damage and rainfall was reported by farmers in the Darfur region of the Sudan [19], and this is consistent with the general notion that peak termite attack on crops and trees occurs during dry periods [20]. This could therefore, explain why termites were a problem most in Moyo district which is relatively drier than the other districts visited. Other pests reported included; mango scales (40\%) and Mealy bugs $(35.6 \%)$.

In general, pest incidence was correlated with pest severity at $5 \%$ level of significance (Kendall's tau- $\mathrm{b}=0.25, \mathrm{P}<0.05$ ). Estimated yield loss due to insect pests was strongly correlated to estimated pest severity at $0.1 \%$ level of significance (Kendall's tau- $\mathrm{b}=0.41, \mathrm{P}<0.001$ ). Table 1 . 
Table 1. Percentage of farmers estimating incidence, severity and yield loss of major mango pests in different districts of West Nile Zone.

\begin{tabular}{|c|c|c|c|c|c|c|c|c|c|c|c|c|c|c|c|c|c|c|c|c|c|}
\hline \multirow{2}{*}{ Pest } & \multicolumn{6}{|c|}{ Incidence } & \multirow{2}{*}{ Cramer's v } & \multicolumn{6}{|c|}{ Severity } & \multirow{2}{*}{ Cramer's v } & \multicolumn{6}{|c|}{ Yield loss } & \multirow{2}{*}{ Cramer's v } \\
\hline & Ar & Ma & Ko & Yu & Mo & $\mathrm{Ne}$ & & $\mathbf{A r}$ & Ma & Ko & Yu & Mo & $\mathrm{Ne}$ & & $\mathbf{A r}$ & Ma & Ko & Yu & Mo & $\mathrm{Ne}$ & \\
\hline \multicolumn{22}{|l|}{ Fruit fly } \\
\hline Low & 0 & 0 & 0 & 0 & 0 & 0 & & 13 & 0 & 15 & 29 & 0 & 0 & & 13 & 0 & 0 & 0 & 0 & 33 & \\
\hline Moderate & 27 & 27 & 38 & 64 & 0 & 25 & $0.40 *$ & 27 & 0 & 0 & 42 & 45 & 50 & $0.43 * *$ & 33 & 0 & 38 & 57 & 27 & 58 & $0.47 * * *$ \\
\hline High & 73 & 73 & 62 & 36 & 100 & 75 & & 60 & 100 & 85 & 29 & 55 & 50 & & 54 & 100 & 62 & 43 & 73 & 9 & \\
\hline \multicolumn{22}{|l|}{ Seed borer } \\
\hline Low & 0 & 10 & 10 & 10 & 10 & 40 & & 60 & 30 & 40 & 0 & 50 & 0 & & 90 & 40 & 60 & 30 & 80 & 0 & \\
\hline Moderate & 50 & 30 & 40 & 40 & 30 & 10 & $0.29 \mathrm{NS}$ & 40 & 20 & 60 & 60 & 50 & 70 & $0.47 * * *$ & 10 & 10 & 40 & 30 & 20 & 70 & $0.51 * * *$ \\
\hline High & 50 & 60 & 50 & 50 & 60 & 50 & & 0 & 50 & 0 & 40 & 0 & 30 & & 0 & 50 & 0 & 40 & 0 & 30 & \\
\hline \multicolumn{22}{|l|}{ Termites } \\
\hline Low & 43 & 0 & 56 & 25 & 33 & 0 & & 43 & 17 & 13 & 0 & 44 & 67 & & 57 & 17 & 38 & 17 & 56 & 67 & \\
\hline Moderate & 43 & 33 & 33 & 13 & 11 & 67 & $0.43 \mathrm{NS}$ & 29 & 17 & 75 & 33 & 56 & 33 & $0.52 *$ & 14 & 66 & 12 & 50 & 11 & 33 & $0.40 \mathrm{NS}$ \\
\hline High & 14 & 67 & 11 & 38 & 56 & 33 & & 28 & 66 & 12 & 67 & 0 & 0 & & 29 & 17 & 50 & 33 & 33 & 0 & \\
\hline \multicolumn{22}{|l|}{ Scales } \\
\hline Low & 20 & 0 & 0 & 0 & 0 & 0 & & 40 & 0 & 0 & 50 & 25 & 50 & & 40 & 0 & 60 & 50 & 25 & 50 & \\
\hline Moderate & 20 & 63 & 50 & 50 & 25 & 63 & $0.40 \mathrm{NS}$ & 0 & 57 & 60 & 0 & 50 & 13 & $0.46 \mathrm{NS}$ & 40 & 71 & 20 & 50 & 25 & 0 & $0.45 \mathrm{NS}$ \\
\hline High & 60 & 37 & 50 & 50 & 75 & 37 & & 60 & 43 & 40 & 50 & 25 & 37 & & 20 & 29 & 20 & 0 & 50 & 50 & \\
\hline \multicolumn{22}{|l|}{$\begin{array}{l}\text { Mealy } \\
\text { bugs }\end{array}$} \\
\hline Low & 33 & 0 & 38 & 13 & 0 & 0 & & 67 & 50 & 0 & 0 & 40 & 50 & & 67 & 0 & 38 & 0 & 60 & 50 & \\
\hline Moderate & 67 & 25 & 0 & 37 & 60 & 67 & $0.47 \mathrm{NS}$ & 33 & 0 & 50 & 50 & 60 & 0 & $0.51 *$ & 33 & 50 & 0 & 13 & 0 & 50 & $0.56^{* *}$ \\
\hline High & 0 & 75 & 62 & 50 & 40 & 33 & & 0 & 50 & 50 & 50 & 0 & 50 & & 0 & 50 & 62 & 87 & 40 & 0 & \\
\hline
\end{tabular}

a. Chi-squared was used to test significance. $\mathrm{NS}=$ not significant, $*$ significant at $10 \%$ level, $* *$ significant at $5 \%$ level, $* * *$ at $1 \%$ level

b. $\mathrm{Ar}=$ Arua, $\mathrm{Ma}=$ Maracha, $\mathrm{Ko}=$ Koboko, $\mathrm{Yu}=$ Yumbe, $\mathrm{Mo}=$ Moyo and $\mathrm{Ne}=$ Nebbi district

\subsubsection{Diseases}

Farmers' knowledge about diseases was less extensive than their knowledge about pests, and the attributed yield losses due to diseases were lower. This sharply contrasts with [13] who reported higher attributed yield losses due to diseases by farmers in Vietnam.

Anthracnose ( $C$. gloeosporioides) was the most mentioned $(89.8 \%)$ mango disease in West Nile zone. Its incidence and severity were estimated significantly high in Maracha district ( $p=0.04$ and $p=0.009$ ) respectively. The high incidence and severity estimates of the disease in Maracha district could be attributed to close spacing of the mangoes. During the survey it was noted that most mangoes in Maracha district were spaced $6 \mathrm{~m}$ by $6 \mathrm{~m}$ and the crowns had intertwined. Such close spacing promotes wet, humid, warm conditions that favor anthracnose infections in the field [11].

Bacterial black spot (Xanthomonas campestris $p v$ mangiferae-indicae) was prevalent in all the districts visited. It was mentioned by $67.8 \%$ of the respondents. The severity and yield loss due to the disease were rated significantly high in
Moyo district ( $p=0.01$ and $p=0.000$ ) respectively. This implies that Moyo district experiences high rainfall and temperatures concomitantly, a condition that is reported by [9] to escalate the disease. Since the commonest mode of spread of the disease is through infected planting materials [21] it means that most seedlings planted in Moyo district were infected.

Powdery mildew (O. mangiferae) was another important mango disease in WNZ reported by $58.8 \%$ of the respondents. The diseases was encountered most in Koboko district (64\%). Under severe blossom and fruit infection, crop losses due to powdery mildew attack have been reported to be high [10]. This is because the affected flowers and fruits drop pre-maturely, reducing the crop load considerably or might even prevent fruit set. This explains why there was a relationship between severity and yield loss due to powdery mildew in Moyo district. Both were rated significantly high. Other mango diseases mentioned included Algal leaf spot $(C$. virescens) and sooty mould (Table 2 ).

From these results it is clear that most mango diseases reported in the zone were fungal in nature.

Table 2. Percentage of farmers estimating incidence, severity and yield loss of major mango diseases in different districts of West Nile Zone.

\begin{tabular}{|c|c|c|c|c|c|c|c|c|c|c|c|c|c|c|c|c|c|c|c|c|c|}
\hline \multirow{2}{*}{ Disease } & \multicolumn{6}{|c|}{ Incidence } & \multirow{2}{*}{ Cramer's v } & \multicolumn{6}{|c|}{ Severity } & \multirow{2}{*}{ Cramer's v } & \multicolumn{6}{|c|}{ Yield loss } & \multirow{2}{*}{ Cramer's v } \\
\hline & Ar & Ma & Ko & $\mathbf{Y u}$ & Mo & $\mathrm{Ne}$ & & Ar & Мa & Ko & Yu & Mo & $\mathrm{Ne}$ & & Ar & Ma & Ko & $\mathbf{Y u}$ & Mo & $\mathrm{Ne}$ & \\
\hline \multicolumn{22}{|c|}{ Anthracnose } \\
\hline Low & 17 & 14 & 23 & 29 & 36 & 29 & \multirow{3}{*}{$0.34 * *$} & 42 & 36 & 0 & 23 & 07 & 43 & \multirow{3}{*}{$0.38 * * *$} & 25 & 14 & 38 & 46 & 50 & 64 & \multirow{3}{*}{$0.39^{* * *}$} \\
\hline Moderate & 33 & 21 & 15 & 14 & 43 & 64 & & 25 & 21 & 62 & 77 & 64 & 50 & & 50 & 64 & 15 & 38 & 0 & 29 & \\
\hline High & 50 & 65 & 62 & 57 & 21 & 07 & & 33 & 43 & 38 & 0 & 29 & 07 & & 25 & 21 & 46 & 15 & 50 & 7 & \\
\hline \multicolumn{22}{|c|}{$\begin{array}{l}\text { Bacterial black } \\
\text { spot }\end{array}$} \\
\hline Moderate & 40 & 50 & 80 & 75 & 42 & 40 & \multirow[t]{2}{*}{$0.35 \mathrm{NS}$} & 60 & 75 & 0 & 25 & 0 & 50 & \multirow[t]{2}{*}{$0.52 * *$} & 0 & 0 & 60 & 75 & 57 & 60 & \multirow[t]{2}{*}{$0.57 * * *$} \\
\hline High & 20 & 25 & 20 & 0 & 42 & 10 & & 40 & 25 & 40 & 0 & 43 & 0 & & 20 & 25 & 40 & 0 & 43 & 0 & \\
\hline
\end{tabular}




\begin{tabular}{|c|c|c|c|c|c|c|c|c|c|c|c|c|c|c|c|c|c|c|c|c|c|}
\hline \multirow{2}{*}{ Disease } & \multicolumn{6}{|c|}{ Incidence } & \multirow{2}{*}{ Cramer's v } & \multicolumn{6}{|c|}{ Severity } & \multirow{2}{*}{ Cramer's v } & \multicolumn{6}{|c|}{ Yield loss } & \multirow{2}{*}{ Cramer's v } \\
\hline & $\mathbf{A r}$ & Ma & Ko & $\mathbf{Y u}$ & Mo & $\mathrm{Ne}$ & & $\mathbf{A r}$ & Ma & Ko & Yu & Mo & $\mathrm{Ne}$ & & Ar & Ma & Ko & Yu & Mo & $\mathrm{Ne}$ & \\
\hline \multicolumn{22}{|c|}{ Algal leaf spot } \\
\hline Low & 20 & 18 & 22 & 9 & 11 & 17 & \multirow{3}{*}{$0.14 \mathrm{NS}$} & 0 & 18 & 33 & 27 & 44 & 50 & \multirow{3}{*}{$0.39 *$} & 40 & 55 & 22 & 9 & 44 & 33 & \multirow{3}{*}{$0.40 * *$} \\
\hline Moderate & 40 & 27 & 44 & 45 & 33 & 33 & & 60 & 55 & 11 & 9 & 44 & 33 & & 20 & 0 & 33 & 36 & 56 & 33 & \\
\hline High & 40 & 55 & 33 & 45 & 56 & 50 & & 40 & 27 & 56 & 64 & 11 & 17 & & 40 & 45 & 44 & 55 & 0 & 0 & \\
\hline \multicolumn{22}{|l|}{$\begin{array}{l}\text { Powdery } \\
\text { mildew }\end{array}$} \\
\hline Low & 0 & 10 & 36 & 25 & 20 & 50 & \multirow{3}{*}{$0.42 *$} & 30 & 40 & 9 & 0 & 40 & 50 & \multirow{3}{*}{$0.44 * *$} & 60 & 60 & 36 & 0 & 0 & 0 & \multirow{3}{*}{$0.54 * * *$} \\
\hline Moderate & 60 & 40 & 0 & 25 & 60 & 50 & & 70 & 50 & 36 & 50 & 0 & 17 & & 0 & 0 & 64 & 50 & 40 & 67 & \\
\hline $\begin{array}{l}\text { High } \\
\text { Sooty mou }\end{array}$ & 40 & 50 & 64 & 50 & 20 & 0 & & 0 & 10 & 55 & 50 & 60 & 33 & & 40 & 40 & 0 & 50 & 60 & 33 & \\
\hline Low & 29 & 33 & 0 & 34 & 25 & 60 & \multirow{3}{*}{$0.25 \mathrm{NS}$} & 43 & 11 & 33 & 17 & 25 & 20 & \multirow{3}{*}{$0.24 \mathrm{NS}$} & 43 & 22 & 100 & 17 & 42 & 40 & \multirow{3}{*}{$0.36 \mathrm{NS}$} \\
\hline Moderate & 43 & 22 & 67 & 33 & 38 & 20 & & 29 & 67 & 34 & 50 & 38 & 60 & & 29 & 44 & 0 & 67 & 29 & 20 & \\
\hline High & 29 & 44 & 33 & 33 & 38 & 20 & & 29 & 22 & 33 & 33 & 38 & 20 & & 29 & 33 & 0 & 16 & 29 & 40 & \\
\hline
\end{tabular}

a. Chi-squared was used to test significance. $\mathrm{NS}=$ not significant, * significant at $10 \%$ level, $* *$ significant at $5 \%$ level, $* * *$ at $1 \%$ level.

b. $\mathrm{Ar}=$ Arua, $\mathrm{Ma}=$ Maracha, $\mathrm{Ko}=$ Koboko, $\mathrm{Yu}=$ Yumbe, $\mathrm{Mo}=$ Moyo and $\mathrm{Ne}=$ Nebbi district.

\subsection{Orchard Management Practices}

Weeding was the most common orchard management practice, mentioned by over $92 \%$ of the respondents. The popularity of this practice could be attributed to the type of orchards established in the region. It was noted that most orchards in the region were intercropped with annual crops that required regular weeding for their good performance. Therefore, in the process of weeding the annual crops, the mangoes benefitted along. Use of herbicides to control weeds in mango orchards was very low among the mango farmers. Yet [22] reported that at some stage, use of herbicides to control weeds in fruit orchards is very ideal because it does not temper with the root system of the trees.

An equal percentage $(50 \%)$ of respondents reported mulching and pruning, while application of manure to improve soil fertility was mentioned by $48.9 \%$. About $43 \%$ of the farmers mentioned spraying to control pests and diseases.

Irrigation as one of the orchard management practices was not mentioned by any of the respondents in the zone. This because most mango farmers in the zone depended on rainfall, with irrigation either too expensive or not available. The farmers believed that the region still received enough rains that met the water requirements of the mangoes. Besides, mangoes were perceived by farmers as hard crops that can withstand long dry seasons. Such kind of beliefs made farmers not to provide additional water for the mangoes during dry season.

Although farmers employed some orchard management practices in their fields, they did not do it the right way. As such, most mango farmers interviewed lacked basic skills on good orchard management practices. This finding is consistent with [4] who reported poor management of orchards in Uganda. Consequently, orchards were unscientifically managed in terms of irrigation at critical stages, tree nutrition, pruning, disease and insect pest management. In the study area, mango was a commonly neglected crop in terms of management, but became important only during the harvesting season. This resulted in low and poor quality production in the zone.

\subsection{Factors that Determine Management Practices Employed by Farmers}

A descriptive summary of the explanatory variables is shown in (Table 3 ) and the results of the Multinomial logit regression are shown in (Table 4). The management practice with the highest frequency in the choice set was taken as the base category. In all cases "weeding" had the highest frequency and was therefore the base category.

The average age of mangoes was 7.4 years and ranged from 5 to 13 years; suggesting that most farmers had some experience in management of mangoes. The respondents had an average age of 36 years.

Table 3. Description of explanatory variables $(N=90)$.

\begin{tabular}{lll}
\hline Variable & Measurement & Expected sign \\
\hline Age of mangoes & Continuous & + \\
Gender & Dummy $(1=$ male, 0 = female & $+/-$ \\
Age of respondents & Continuous & $+/-$ \\
& Dummy $(0=$ No education, 1 = & \\
Educational level & Primary, 2 = Secondary, 3 = & + \\
& Institution and 4 = University) & \\
Extension Services & Dummy $(1=$ Yes, 0 = No) & + \\
\hline
\end{tabular}

Table 4. Factors affecting mango orchard management practices adopted by farmers in West Nile zone.

\begin{tabular}{|c|c|c|c|c|c|c|c|c|}
\hline \multirow{3}{*}{$\begin{array}{l}\text { Independent } \\
\text { Age of mangoes }\end{array}$} & \multicolumn{2}{|l|}{ Pruning } & \multicolumn{2}{|c|}{$\begin{array}{l}\text { Spraying (pests and } \\
\text { diseases) }\end{array}$} & \multicolumn{2}{|l|}{ Manuring } & \multicolumn{2}{|c|}{ Mulching } \\
\hline & B & $\mathrm{P}$ - value & $\mathrm{B}$ & P-value & B & P-value & $\mathrm{B}$ & P-value \\
\hline & $2.442 * * *$ & 0.002 & 0.495 & 0.406 & -0.121 & 0.835 & -0.718 & 0.340 \\
\hline Education level & 0.807 & 0.131 & $0.796^{*}$ & 0.086 & 0.466 & 0.277 & 0.441 & 0.341 \\
\hline Sex & 0.111 & 0.937 & -1.309 & 0.354 & 0.860 & 0.403 & $2.202 * *$ & 0.037 \\
\hline Age of respondents & -0.257 & 0.585 & -0.230 & 0.593 & 0.045 & 0.908 & -0.092 & 0.843 \\
\hline Extension services & $4.537 * * *$ & 0.001 & $4.857 * * *$ & 0.000 & $3.400 * * *$ & 0.005 & $2.373 *$ & 0.073 \\
\hline
\end{tabular}

*** Significant at $1 \%$, ** Significant at $5 \%$ and $*$ Significant at $10 \%$. 
Age of mangoes, education level of farmers, sex and extension services significantly influenced mango orchard management practices adopted by farmers at different levels of significance. Age of respondents had no significant influence on any of the management practices adopted by mango farmers (Table 4).

\subsection{The Management Practices and Factors that Influenced Farmers' Choice of the Practices}

Pruning as a management practice was significantly influenced by age of mangoes and extension services at ( $p=$ 0.002 and $p=0.001$ ) respectively. Generally, as the mango trees grow old, more branches form and the canopy expands. This warrants pruning to shape the trees and open up the centers, allowing free movement of air and sunlight into the tree and the crops beneath. Similarly, extension services also significantly influenced pruning of mangoes. This is because, extension probably equipped farmers on advantages of pruning and how to practically carry out pruning hence enabling them to prune their trees.

Spraying against pests and diseases (pesticide use) was positively related to extension contact and was significant at 1 percent $\alpha$ level. Thus an increase in extension contact increased the probability of adoption of pesticide use in mango production in the study area by 4.857 . The result is at variance with [23] who found a negative correlation between extension contact and pesticide use in rice production in Ghana. The result is however consistent with [24] who found a positive relation between agrochemical use and extension contact. From our study, we deduce that as farmers contact with extension agents increase, they are able to get more information on use and management of pesticides. Hence an increase in extension contacts increases the likelihood of pesticide use in mango production by farmers.

Spraying against pests and diseases was also positively influenced by education level of farmers at 10 percent level of significance. This implies that the tendency to spray mango orchards increased with increase in education level of farmers. This is possible because, education helps farmers to read and follow instructions on pesticide containers. Understanding such instructions prevents farmers from misuse of pesticides, hence promoting their usage. This result is in tandem with [25], who reported a positive influence of education level on pesticide use among citrus farmers in Pakistan, but sharply contrasts with [23] who found no significant influence of education level on pesticide use among rice farmers in Ghana.

Manuring of mango orchards was significantly and positively influenced by access to extension service at 1 percent $\alpha$ level. From Table 4 it is evident that a unit increase in extension contacts increases the probability of manuring by 3.4. This is possibly so because extension services inform farmers on the benefits of manuring their orchards, hence promoting the practice. The results are in agreement with [26] who reported a significant influence of extension services on manuring among maize farmers in Kenya.

The ability of farmers to mulch their mango orchards were significantly influenced by sex of the respondents and extension contact at 5 and 10 percent $\alpha$ level respectively. Mulching was done to protect the roots and base of plants from extreme temperature, moisture changes and improve the quality of the soil and also stop the growth of weeds. Mulching in the zone was mostly done using dry grass and crop residues from the fields. The magnitude of the work could explain why sex had a significant influence on the practice. This is because, in West Nile zone, men are believed to engage in hard laborious work like, pruning, spraying and digging among others. Women usually engage in less risky light work like harvesting weeding of crops among others. It was noted during the interviews that mulching was considered a less laborious work, hence fit for women. Besides, the materials used for mulching made the practice to be mostly done by women. Therefore, based on the nature of the work the significant influence of sex is justifiable. This result contrasts with [27] who found no significant influence of sex on mulching.

\section{Conclusion}

The results of this study reveal that farmers' perception on incidence, severity and yield loss due to the different pests and diseases varied across the districts. The five major pests and diseases believed to cause enormous destruction to mangoes in the zone include: fruit flies, seed borer termites, scales and mealy bugs for pests and anthracnose, bacterial black spot, powdery mildew, algal leaf spot and sooty mould for diseases. The knowledge level of farmers on most mango pests and diseases in the zone was low. Good orchard management practices like timely pruning, spraying, weeding, manuring and mulching were still lacking among the mango farmers. The many pests and diseases coupled with unsound scientific orchard management practices threaten the zone's exotic mango production potential. Therefore, to improve exotic mango production in the zone, awareness creation among farmers about the various mango pests and diseases is vital. There is also need to build the capacity of farmers and extension staff on scientific orchard management practices as a key to development of mango industry in the zone. Future studies should focus on development of technologies for control of mango fruit fly and anthracnose that were the most rated pest and disease in the zone respectively.

\section{Acknowledgment}

This work was supported by the Agricultural Technology Agribusiness and Advisory Services Project, funded by the International Development Agency. 


\section{References}

[1] Banerjee G. D. 2011. Economics of Mango Cultivation. Published by the National Bank for Agriculture and Rural Development, Department of Economic Analysis and Research, $4^{\text {th }}$ Floor, 'C' Wing, Plot No. C-24, G-Block, PB No. 8121, Bandra-Kurla Complex, Bandra (East), Mumbai400051 .

[2] UIA 2009. Investment Potentials in Mango Farming Sector in Uganda. 13pp.

[3] Okoth E. M, Sila D. N, Onyango C. A, Owino. W. O, Musembi S. M and Mathooko F. M. 2013. Evaluation of physical and sensory quality attributes of three mango varieties at three stages of ripeness, grown in lower eastern province of Kenya - part 1. Journal of Animal \&Plant Sciences, 2013. Vol. 17, Issue 3: 2608-2618.

[4] FIT Uganda 1td. 2007. Final report of a study on fruits (Pineapples, Passion fruit and mangoes) sub sector in Uganda. $124 \mathrm{pp}$.

[5] Fita T, 2014. White Mango Scale, Aulacaspis tubercularis, Distribution and Severity Status in East and West Wollega Zones, Western Ethiopia. Sci. Technol. Arts Res. J., 3 (3): 0110.

[6] Verghese, A. 2000. Recent studies on the management of mango stone weevil Sternochetus mangiferae Fab. (Coleoptera: Curculionidae) in South India, Acta Horticulturae, 509: 819-822.

[7] Barbara W. E and Bradley F. M. 2012 Pest, Disease and Weed Management Plan. Agriculture and Land-Based Training Association; Farmer Education Program (PEPA) Resource Guide.

[8] Nankinga C. M., Isabirye B. E., Muyinza H., Rwomushana I., Stevenson P. C., Mayamba A., Aool W. and Akol A. M 2014. Fruit fly infestation in mango: A threat to the Horticultural sector in Uganda. Uganda Journal of Agricultural Sciences, 15 (1): $1-14$

[9] Gagnevin L and Pruvost O. 2001 Epidemiology and Control of Mango Bacterial Black Spot Plant Disease / Vol. 85 No. 9.

[10] Nofal M. and Hagga W. M 2006. Integrated management of Powdery Mildew of Mango in Egypt. Crop protection 25 (5) 480-486.

[11] Nelson S. C. 2008. Mango anthracnose (Colletotrichum gloeosporioides) Department of Plant and Environmental Protection Sciences.

[12] Bebber D. P, Holmes T and Gurr S. J. 2014. The global spread of crop pests and pathogens. Global Ecology and Biogeography, (Global Ecol. Biogeogr.) 23, 1398-1407.

[13] Van Mele P, Cuc N. Thi Thu and Van Huis A. 2001. Farmers' Knowledge, Perceptions and Practices in Mango Pest Management in the Mekong Delta, Vietnam. International Journal of Pest Management, 2001, 47 (1) 7-16.
[14] Greene, W. H. 2003. Econometric analysis. Fifth edition. Prentice Hall, Upper Saddle River, New Jersey, Prentice Hall. 1026pp.

[15] Greene, W. H. 2000. Econometric Analysis, 4th edition. New Jersey: Prentice Hall.

[16] Price, T. V., ed., 2006. Pest and disease incursions: risks, threats and management in Papua New Guinea. Papers presented at the 2nd Papua New Guinea Plant Protection Conference, Kokopo, East New Britain Province, 8-10 November 2004. Canberra, ACIAR Technical Reports No. 62, 199p.

[17] Drew, R. A. I., Tsuruta K. and White I. M. 2005. A new species of pest fruit fly (Diptera: Tephritidae: Dacinae) from Sri Lanka and Africa. Afr. Entomol. 13: 149-154.

[18] Nyeko P and Olubayo F. M. 2005. Participatory Assessment of Farmers' Experiences of Termite Problems in Agroforestry in Tororo District, Uganda. Agricultural Research \& Extension Network paper No. 143.

[19] Pearce, M. J., Logan, J. W. M. and Tiben, A. 1995. Termites (Isoptera) from the Darfur region of the Sudan with comments on their pest status Journal of Arid Environment, Vol. 30, pp. 197-206.

[20] Logan, JW. M., Cowie, R. H. and Wood, T. G. 1990. 'Termites (Isoptera) control in agriculture and forestry by non-chemical methods: A review', Bulletin of Entomological Research, Vol. 80, No. 3, pp. 309-30.

[21] Pitkethley R. 2006. Bacterial Black Spot of Mangoes. Department of Primary Industry, Fisheries and Mines Northern Territory Government. ISSN 0157-8243.

[22] Pearson A. J 2003 Trends in weed management in New Zealand orchards New Zealand plant protection 56: 211-214.

[23] Anang B. T and Amikuzuno J. 2015. Factors Influencing Pesticide Use in Smallholder Rice Production in Northern Ghana Agriculture, Forestry and Fisheries; 4 (2): 77-82 doi: 10.11648/j.aff.20150402.19.

[24] Adeola, R. G. 2012. Perceptions of Environmental Effects of Pesticides Use in Vegetable Production by Farmers in Ogbomoso, Nigeria. Global Journal of Science Frontier Research Agriculture \& Biology Volume 12 Issue 4 Version 1 Global Journals Inc. (USA).

[25] Yasin G, Aslam M, Parvez I. and Naz S. 2003. Socioeconomic Correlates of Pesticide Usage: The Case of Citrus Farmers. Journal of Research (Science), Bahauddin Zakariya University, Multan, Pakistan 14 (1): 43-48.

[26] Waithaka M. M, Thornton P. K, Shepherd K. D and Ndiwa N. N. 2007. Factors affecting the use of fertilizers and manure by smallholders: the case of Vihiga, western Kenya. Nutr Cycl Agroecosyst; 78: 211-224. doi: 10.1007/s10705-006-9087-x.

[27] Akinola A. and Owombo P. 2012. Economic Analysis of Adoption of Mulching Technology in Yam Production in Osun State, Nigeria. International Journal of Agriculture and Forestry; 2 (1): 1-6. doi: 10.5923/j.ijaf.20120201.01. 